\title{
Jurnal Rekayasa Material, Manufaktur dan Energi http://jurnal.umsu.ac.id/index.php/RMME
}

\section{Analisa Produktivitas Kerja Mesin Pemecah Buah Aren Sistem Translasi Vertikal Kapasitas 50 Kg/Jam}

\author{
Franky sutrisno*), Willy pratama, Nurdiana, Toni Siagian, Yulfitra, Eswanto \\ Jurusan Teknik Mesin, Fakultas Teknologi Industri, Institut Teknologi Medan \\ Jl.Gedung Arca No 52 Medan, 20271 \\ *Email : ir.franky.s@gmail.com; nurdiana@itm.ac.id; eswanto@itm.ac.id
}

\begin{abstract}
ABSTRAK
Mesin pemecah buah aren adalah mesin yang digunakan untuk proses pemecahan buah aren.Mesin yang di uji berkapasitas $50 \mathrm{~kg} / \mathrm{jam}$ menggunakan mekanisme poros,roda gigi,puli ,elektro motor dan reduser. Pengujian ini dilakukan untuk mengetahui kapasitas produksi, kualitas, daya produksi dan effisiensi mesin, pelaksanaan uji dilakukan dari bahan baku yang digunakan adalah aren dengan density yaitu $0.70 \mathrm{~kg} /$ liter dengan ukuran rata-rata diameter $5 \mathrm{~cm}$.Dari hasil pengujian ternyata diperoleh kapasitas maximum sebesar $23,74 \mathrm{~kg} / \mathrm{jam}$ untuk aren density $0.70 \mathrm{~kg} / \mathrm{liter}$ yang bekerja pada putaran $72 \mathrm{rpm}$, sedangkan density $0.70 \mathrm{~kg} /$ liter kapasitas maximum $19,047 \mathrm{~kg} / \mathrm{jam}$ yang bekerja pada putaran $60 \mathrm{rpm}$, kapasitas maximum sebesar $15,78 \mathrm{~kg} / \mathrm{jam}$ untuk aren density $0.70 \mathrm{~kg} /$ liter yang bekerja pada putaran $48 \mathrm{rpm}$, yang cenderung diakibatkan oleh gaya inersia yang dihasilkan dari putaran, effisiensi mesin dan daya produksi untuk density $0.70 \mathrm{~kg} /$ liter pada putaran $60 \mathrm{rpm}$ besarnya effisiensi mesin $11,5 \%$ dengan daya produksi $16,43 \mathrm{watt} / \mathrm{kg}$ sedangkan untuk density $0,70 \mathrm{~kg} /$ liter pada putaran $72 \mathrm{rpm}$ effisiensi mesin $40,1 \%$ dengan daya produksi $16,63 \mathrm{watt} / \mathrm{kg}$ pada putaran $48 \mathrm{rpm}$ effisiensi mesin $15,7 \%$ dengan daya produksi $16,7 \mathrm{watt} / \mathrm{kg}$.
\end{abstract}

Kata kunci : kapasitas, kualitas,effisiensi dan daya produksi

\section{Work Productivity Analysis Palm Sugar Breaking Machine Vertical Translation System Capacity $50 \mathrm{Kg} /$ Hour}

\begin{abstract}
Palm sugar breaking machine is a machine that is used for the process of breaking palm fruit.The machine tested with a capacity of $50 \mathrm{~kg} /$ hour uses a shaft mechanism, gears, pulleys, electro motors and reducers. This test was carried out to determine the production capacity, quality, production power and engine efficiency, the implementation of the test carried out from the raw materials used was palm with a density of $0.70 \mathrm{~kg} /$ liter with an average size of $5 \mathrm{~cm}$ diameter. $23.74 \mathrm{~kg} /$ hour for palm density $0.70 \mathrm{~kg} /$ liter which works at $72 \mathrm{rpm}$, while the density is $0.70 \mathrm{~kg} /$ liter maximum capacity of $19.047 \mathrm{~kg} /$ hour working at $60 \mathrm{rpm}$, maximum capacity of $15.78 \mathrm{~kg} /$ hour for sugar palm density of $0.70 \mathrm{~kg} /$ liter which works at $48 \mathrm{rpm}$, which tends to be caused by inertial forces resulting from rotation, engine efficiency and production power for densities of $0.70 \mathrm{~kg} /$ liter at $60 \mathrm{rpm}$ the size of engine efficiency is $11.5 \%$ with a production power of 1643 watts / $\mathrm{kg}$ while for density $0.70 \mathrm{~kg} /$ liter at $72 \mathrm{rpm}$ the engine efficiency is $40.1 \%$ with a production power of 16.63watt / $\mathrm{kg}$ at $48 \mathrm{rpm}$ the engine efficiency is $15.7 \%$ with pro produce 16.7 watts / $\mathrm{kg}$.
\end{abstract}

Keywords: capacity, quality, efficiency and production power

\section{Latar Belakang}

\section{PENDAHULUAN}

Perkembangan ilmu dan teknologi ditinjau dari peningkatan produk baik kuantitas maupun kualitas, sesungguhnya dibutuhkan ide bagaimana cara untuk menerapkan metode yang paling

Copyright ${ }^{\odot} 2019$ Jurnal Rekayasa Material, Manufaktur dan Energi. This is an open acces article under the CC-BY-SA lisence (https://creativecommons.org/licenses/by-sa/4.0/). 


\section{Published Maret 2019 \\ Jurnal Rekayasa Material, Manufaktur dan Energi http://jurnal.umsu.ac.id/index.php/RMME}

tepat untuk melakukan peningkatan kualitas produk serta peningkatan produk tetapi dapat pula menekan harga produksinya.

Sebagaimana telah diketahui bahwa seiring berkembangnya ilmu pengetahuan dan teknologi cenderung kepada adanya tuntutan zaman serta dapat memenuhi kebutuhan masyarakat.Sehingga berbagai cara orang mencari dan berusaha melakukan modifikasi-modifikasi mesin untuk memperoleh hasil yang efisiensi dan efektif, untuk menghasilkan produk yang baik. Padaindustri rumah tangga dalam menghasilkan aren dimana Permintaan konsumen dan sulitnya proses pengolahan dalam menghasilkan. Aren membuat industri ini seringkali terkendala di dalam proses pengolahan dimana membutuh tenaga yang sangat ekstra dalam mengolah salah satu kuliner yang masih tergolong tradisional ini.

Untuk menyelesaikan masalah diatas maka dibutuhkan sebuah alat teknologi tepat guna yang dapat mempermudah tenaga kerja manusia, agar kapasitas persatuan waktu dapat ditingkatkan dengan hasil pengupasan yang lebih baik lagi dari sebelumnya dengan cara manual, dimana pengupasannya dilakukan secara memasak atau membakar kulit atau sabuk dari aren dan akhirnya dapat menekan biaya produksi.

Dari uraian di atas maka penulis tertarik untuk melakukan analisa uji kerja untuk membutuhkan bahwa alat yang dirancang bekerja sesuai rencana, hal ini yang menjadi dasar tugas akhir penulis adapun judul dari tugas akhir ini adalah "Analisa analisakerja mesin pemecah buah aren sistem translasi vertikal kapasitas $50 \mathrm{~kg} / \mathrm{jam}$.

\section{Tujuan umum}

Tujuan umum penulisan ini adalah untuk melakukan uji produktivitas kerja mesin pemecah buah aren sistem translasi vertikal kapasitas $50 \mathrm{~kg} / \mathrm{jam}$

\section{Tujuan khusus}

Adapun tujuan khusus dari pembahasan ini adalah:

- Untuk mengetahui poduktivitas mesin hasil pengujian.

- Untuk mengetahui pengaruh variasi putaran terhadap produktivitas.

- Untuk menekan biaya produksi

\section{Sejarah buah Aren}

\section{TINJAUAN PUSTAKA}

Berbicara tentang sejarah buah aren, banyak para ahli menyakini bahwa tanaman yang satu ini berasal dari Paraguay dan Brasil selatan yang kemudian oleh penduduk lokal dibudidayakan di seluruh Amerika Selatan hingga Kepulauan Karibia.Pada 1493, Christopher Columbus menemukan buah aren di Karibia Guadalupe.Inilah bakal diperkenalkannya buah aren ke benua Eropa yang kemudian menyebar ke seluruh dunia saat era kolonialisme berlangsung.Ketika Columbus memperkenalkan aren ke Eropa, buah aren menjadi sangat populer.Selama masa itu, aren merupakan salah satu makanan mewah yang dianggap sangat eksklusif.Kapal-kapal membawa buah aren yang diawetkan dari pulau-pulau Karibia dan dijual dengan harga sangat mahal di Eropa.

(Sumber : http://arenindonesia.wordpress.com)

\section{Kerangka konsep}

Tujuan dari pengujian ini adalah, mampu menunjukkan hasil kinerja mesin pemecah buah aren sistem translasi vertikal,Untuk Mengetahui Pengaruh Putaran Terhadap Kwalitas Produksi, Untuk Mengetahui Kapasitas produksi, Untuk Mengetahui daya produksi.

\section{Tempat Dan Waktu pengujian}

\section{METODE PENGUJIAN}

- Tempat pengujian serta kegiatan uji coba direncanakan atau dilaksanakan di Bengkel dan di Lab. Proses Produksi Jurusan Teknik Mesin Institut Teknologi Medan (ITM). 


\section{Published Maret 2019 \\ Jurnal Rekayasa Material, Manufaktur dan Energi http://jurnal.umsu.ac.id/index.php/RMME}

- Waktu perancangan mesin ini direncanakan, diperkirakan paling lama enam bulan,

\section{Bahan}

\section{Peralatan}

Pada pengujian kinerja ini mengunakan peralatan yaitu sebagai berikut;

- Konstruksi Mesin
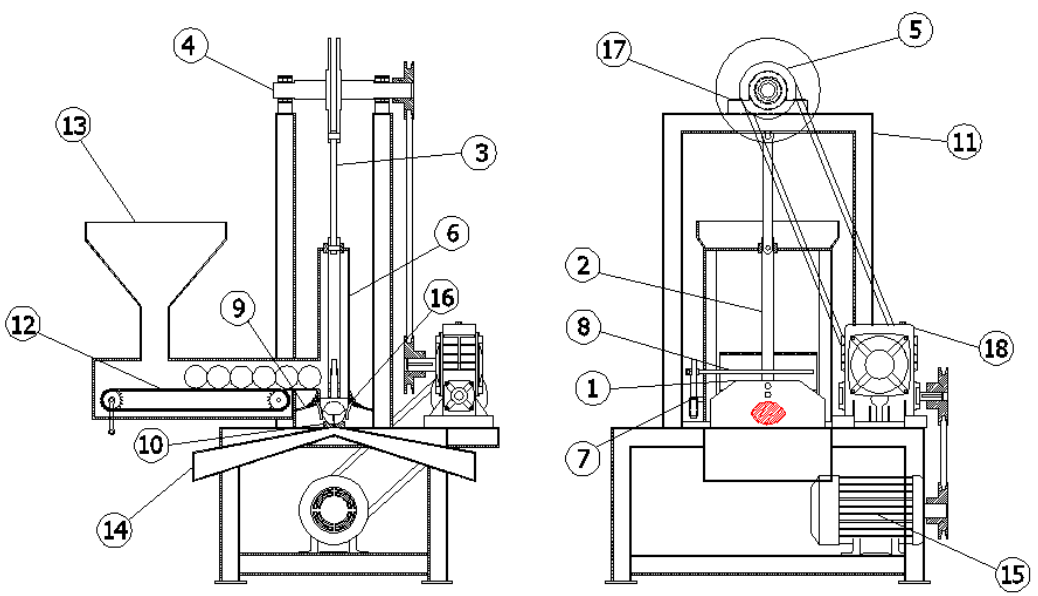

Gambar 2. Konstruksi mesin pemecahbuah aren sistem translasivertikal

Dari gambar dapat dijelaskan bagaimana proses kerja mesin pemecah buah aren, sebagai berikut:

\section{Cara kerja mesin pemecah buah aren dengan metode translasi vertikal}

Sistem kerja dari mesin yang dirancang dijelaskan sebagai berikut: Setelah buah-buah aen dipisahkan dari tangkainya, kemudian dikumpulkan dalam suatu wadah atau tempat penampungan. Operasikan mesin untuk beberapa saat, kemudian susun buah aren ke dalam penampungan saluran masuk (13), ketika motor penggerak (15) menggerakkan puli yang diteruskan dengan sabuk (belt), lalu puli yang berada pada gear box (18) akan berputar dan dari gear box akan memutar puli (5) yang berada pada poros, lalu putar tuas penggerak conveyor (12) maka buah aren yang berada dalam corong penampung akan turun satu persatu bersamaan dengan gerak conveyor. Ketika poros yang digerakkan (4) menggerakkan bandul sekaligus torak (3) berada di TMA maka buah arenakanmasuk ke ruang pemukul, ketika buah arenjatuh kelandasan (10) lalu besi pemukul (1) turun untuk memukul buah aren. Maka buah aren akan dipukul dengan besi pemukul, lalu pintu klep (9) yang terdorong oleh bandul penekan (7) yang bergerak bersamaan dengan besi pemukul akan terbuka, maka buah aren yang telah terbelah akan keluar kesamping kanan dan kiri melewati klep yang telah terbuka oleh bandul penekan dan akan tertampung pada tempat penampungan 


\section{Published Maret 2019 \\ Jurnal Rekayasa Material, Manufaktur dan Energi http://jurnal.umsu.ac.id/index.php/RMME}

yang telah disediakan. Demikian proses pembelah buah aren dilakukan dengan seterusnya akan dapat berlanjut hingga pengoperasian mesin selesai.

\section{HASIL DAN PEMBAHASAN}

Pembahasan dan analisa lebih difokuskan pada yang dituliskan pada tujuan umum, yaitu : AnalisaProduktivitas Kerja Mesin pemecah buah aren sistem translasi vertikal Kapasitas $50 \mathrm{Kg} / \mathrm{Jamdengan}$ hasil yang dapat diterima, maka disusun urutan pembahasannya sesuai tujuan khusus, adapun urut-urutan pembahasannya adalah sebagai berikut:

1. Untuk Mengetahui Produktivitas mesin hasil pengujian

2. Untuk Mengetahui Pengaruhvariasi putaran Terhadap Produktivitas.

3. Analisa uji produktivitaskerja mesin.

\section{Pengaturan Variasi Putaran}

Perencanaan Rangkaian Variasi Putaran

Untuk menentukan variasi putaran pada poros mesin pemecah buah aren ini dilakukan dengan cara merubah diameter roda gigi.

\section{Variasi diameter roda gigi}

Variasi diameter roda gigi yang digerakkan atau roda gigi yang dipasang pada poros mesin pemecah buah aren ini, ada tiga variasi yaitu: masing-masing berdiameter $\left(\mathrm{d}_{2}\right): 15,8(\mathrm{~cm}) ; 12,8(\mathrm{~cm})$ dan $10,57(\mathrm{~cm})$. Sementara diameter roda gigi yang terpasang pada poros reduser adalah $\left(\mathrm{d}_{1}\right)$ adalah 10,57 $(\mathrm{cm})$, dan putaran pada out put reduser $\left(\mathrm{n}_{1}\right)$ adalah $72,5(\mathrm{rpm})$.

\section{Variasi Putaran pada poros pemutar}

Maka ketiga variasi putaran yang dimaksud dapat ditentukan sebagai berikut:

Untuk roda gigi yang berdiameter $\mathrm{d}_{1}=10,5(\mathrm{~cm})$ pada poros yang terpasang pada out put reduserpenggerak dengan putaran 72,5 (rpm).

Untuk roda gigi yang berdiameter $\mathrm{d}_{2}=15,8(\mathrm{~cm}), 12,8(\mathrm{~cm})$ dan $10,57(\mathrm{~cm})$.

Untuk putaran out put reduser di cari dengan melakukan pembagian

$=\frac{\text { putaran motor listrik }}{\text { ratio reduser }}=\frac{1450 \mathrm{rpm}}{20}=72,5 \mathrm{rpm}$

jadi putaran out put pada reduser sebesar $72,5 \mathrm{rpm}$

Untuk mengertahui ketiga variasi putarannya, maka perhitungannya adalah sebagai berikut:

a. Untuk roda gigi yang berdiameter $\mathrm{d}_{2}=15,8(\mathrm{~cm})$ pada poros pemutar yang dihubungkan putaran pada poros motor penggerak dipasangkan sebuah roda gigi $\left(\mathrm{d}_{1}\right)$ juga dengan diameter $=10,5(\mathrm{~cm})$, dan putarannya $=72,5(\mathrm{rpm})$, maka putaran $\mathrm{n}_{2}$, adalah:

$n_{2}=48(\mathrm{rpm})$

Jadi putaran pada pemecah adalah 48 (rpm).

b. Untuk roda gigi yang berdiameter $\mathrm{d}_{2}=12,8(\mathrm{~cm})$ pada poros pemutar yang dihubungkan putaran pada poros motor penggerak dipasangkan sebuah roda gigi $\left(d_{1}\right)$ juga dengan diameter $=10,5$ $(\mathrm{cm})$, dan putarannya $=72,5(\mathrm{rpm})$, maka putaran $\mathrm{n}_{2}$, adalah:

$n_{2}=\frac{d_{1} x n_{1}}{d_{2}} \quad n_{2}=\frac{10,5 \times 72,5}{12,8} \quad n_{2}=60(\mathrm{rpm})$

Jadi putaran pada pemecah adalah 60 (rpm).

c. Untuk roda gigi yang berdiameter $\mathrm{d}_{2}=10,5(\mathrm{~cm})$ pada poros pemutar yang dihubungkan putaran pada poros motor penggerak dipasangkan sebuah roda gigi $\left(\mathrm{d}_{1}\right)$ juga dengan diameter $=10,5(\mathrm{~cm})$, dan putarannya $=72,5(\mathrm{rpm})$, maka putaran $\mathrm{n}_{2}$, adalah: 


\section{Jurnal Rekayasa Material, Manufaktur dan Energi} http://jurnal.umsu.ac.id/index.php/RMME

$$
n_{2}=\frac{d_{1} x n_{1}}{d_{2}} \quad n_{2}=\frac{10,5 \times 72,5}{10,5} \quad n_{2}=72(\mathrm{rpm})
$$

Jadi putaran pada pemecah adalah 72(rpm).
a. $70 \mathrm{~kg} / \mathrm{liter}$
b. Massa
$: 340$ gr
c. Waktu Oprasinal (t) : 64.25detik

Untuk hasil percobaankedua pada mesin pemecah buah aren diperoleh hasilnya dan ditabulasi ke dalam tabel dibawah ini dan hasilnya adalah sebagai berikut:

Tabel 1. Pemecah Buah aren Percobaan Kedua

\begin{tabular}{|l|l|l|l|l|}
\hline \multirow{2}{*}{ No } & \multirow{2}{*}{$\begin{array}{l}\text { Putaran Kerja } \\
(\mathrm{rpm})\end{array}$} & \multicolumn{2}{|l|}{ Jumlah(gr) } & \multirow{2}{*}{$\begin{array}{l}\text { Jumlah } \\
\text { Total (gr) }\end{array}$} \\
\cline { 3 - 4 } & & $\mathrm{Ka}$ & $\mathrm{Kb}$ & \\
\hline 1. & 60 & 275 & 65 & 340 \\
\hline 2. & 60 & 282 & 58 & 340 \\
\hline 3. & 60 & 288 & 52 & 340 \\
\hline \multicolumn{2}{|l}{ Rata-rata } & 282 & 58 & 340 \\
\hline
\end{tabular}

Sumber : Hasil Percobaan

Keterangan : $\mathrm{Ka}=$ buah aren terbelah

1. Percobaan Ketiga

$\mathrm{Kb}=$ buah aren tidak terbelah

a. Jenis : aren

b. Type buah : bulat

c. Density $(\rho \mathrm{a}) \quad: 0.70 \mathrm{~kg} / \mathrm{liter}$

d. Massa : 340 gr

e. Waktu Oprasinal (t) : 51,4detik

Untuk hasil percobaan ketiga pada mesin pemecah buah aren diperoleh hasilnya dan ditabulasi ke dalam tabel dibawah ini dan hasilnya adalah sebagai berikut:

Tabel 2. Pemecah Buah Aren Percobaan Ketiga

\begin{tabular}{|c|c|c|c|c|}
\hline \multirow{2}{*}{ No } & \multirow{2}{*}{$\begin{array}{l}\text { Putaran Kerja } \\
\text { (rpm) }\end{array}$} & \multicolumn{2}{|c|}{ Jumlah (gr) } & \multirow{2}{*}{$\begin{array}{l}\text { Jumlah } \\
\text { Total (gr) }\end{array}$} \\
\hline & & $\mathrm{Ka}$ & $\mathrm{Kb}$ & \\
\hline 1. & 72 & 262 & 78 & 340 \\
\hline 2. & 72 & 270 & 70 & 340 \\
\hline 3. & 72 & 277 & 63 & 340 \\
\hline & Rata-rata & 269 & 71 & 340 \\
\hline
\end{tabular}

Analisa Kapasitas Produksi

Kapasitas produksi Dengan Putaran 48 (rpm)

a. Aren terbelah $\mathrm{ka}=293(\mathrm{gr}=0,228(\mathrm{~kg} /$ menit $)$

b. Aren tidak terbelahkb $=47(\mathrm{gr})=0,0365(\mathrm{~kg} /$ menit $)$

c. Kapasitas total aren $0,70 \mathrm{~kg} / \mathrm{liter}=\mathrm{ka}+\mathrm{kb}$

$\mathrm{Ka}=\mathrm{Buah}$ aren terbelah, $\mathrm{Kb}=$ buah aren tidak terbelah 


\section{Published Maret 2019 \\ Jurnal Rekayasa Material, Manufaktur dan Energi http://jurnal.umsu.ac.id/index.php/RMME}

\section{Analisa Daya}

Dari hasil percobaan pada putaran 48(rpm)diperoleh putaran kwh selama $(\mathrm{t})$ detik adalah $\mathrm{x}$ putaran.

a. Rugi elektro motor di peroleh 127,8 putaran/jam

$\mathrm{R}_{\mathrm{em}}=127,8$ putaran/jam, Daya $=142 \mathrm{Watt}$

b. Rugi mekanisme di peroleh 174 putaran/jam Daya $=193,3$ (Watt)

c. Rugi beban pada $0,70 \mathrm{~kg} / \mathrm{liter}$ Daya $=265$ (Watt)

Sedangkan Dari hasil percobaan pada putaran 60(rpm)diperoleh putaran $\mathrm{kWh}$ selama (t) detik adalah x putaran.
a. Rugi elektro motor di peroleh 127,8 putaran/jam
$\mathrm{R}_{\mathrm{em}}=127,8$ putaran/jam, Daya $=142 \mathrm{Watt}$
b. Rugi mekanisme di peroleh 264 putaran/jam
Rugi beban pada 0,70 kg/litenDaya $=293,33$ (Watt)

\section{Pengaruh Putaran Terhadap Kualitas}

Dari hasil analisa yang telah diperoleh, density buah aren terhadap kualitas hasil adalahsebagai berikut :

1. kondisi aren pada density $0,70 \mathrm{~kg} / \mathrm{literpada}$ putaran $48(\mathrm{rpm})$
a. kondisi aren terbelah $13,68(\mathrm{~kg} / \mathrm{jam}) \quad=86,6 \%$

b. $\quad$ kondisi aren tidak terbelah $2,1(\mathrm{~kg} / \mathrm{jam})=13,30 \%$

2. kondisi aren pada density $0,70 \mathrm{~kg} / \mathrm{literpada}$ putaran $60(\mathrm{rpm})$
a. kondisi aren terbelah $15.798(\mathrm{~kg} / \mathrm{jam}) \quad=82,9 \%$
b. kondisi aren tidak terbelah $3,249(\mathrm{~kg} / \mathrm{jam})=17,05 \%$

3. kondisi aren pada density $0,70 \mathrm{~kg} / \mathrm{literpada}$ putaran $72(\mathrm{rpm})$

c. kondisi aren terbelah18,84(kg/jam) $=79,35 \%$

d. kondisi aren tidak terbelah $4,9(\mathrm{~kg} / \mathrm{jam}) \quad=20,64 \%$

\section{Analisa Produktivitas Mesin Pemecah Buah Aren}

Produktivitas mesin pemecah buah aren ini dapat diketahui sebagai berikut :

1. Kapasitas yang dihasilkan pada percobaan pertama pada density $0,70 \mathrm{~kg} / \mathrm{liter}: 15,78(\mathrm{Kg} / \mathrm{Jam})$ dengan daya yang dihasilkan 265(Watt).

Maka daya produksi mesin ini adalah

Di dapat daya produksi mesin $16,7(\mathrm{Wat} / \mathrm{Kg})$

2. Kapasitas yang dihasilkan pada percobaan kedua pada density 0,70 kg/liter: $19.047(\mathrm{Kg} / \mathrm{Jam})$ dengan daya yang dihasilkan 313 (Watt).

Maka daya produksi mesin ini adalah

Di dapat daya produksi mesin $16,43(\mathrm{Watt} / \mathrm{Kg})$

3. Kapasitas yang dihasilkan pada percobaan pertama pada density $0,70 \mathrm{~kg} / \mathrm{liter}$ : 23,74(Kg/Jam) dengan daya yang dihasilkan 395(Watt).

Maka daya produksi mesin ini adalah

Di dapat daya produksi mesin 16,63 (Watt/Kg)

\section{Analisa putaran kWh}

Dari hasil pengujian dengan putaran $48(\mathrm{rpm})$ diperoleh putaran $\mathrm{kWh}$ selama (t) detik adalah $\mathrm{x}$ putaran,dan di analisa diperoleh :

a. Rugi elektro motor 112.42 detik dalam 4 putaran $\mathrm{kWh}$

$\mathrm{P}_{\mathrm{TB}}=4$ putaran/detik

$$
=127,8 \text { putaran } / \text { jam }
$$

b. Rugi mekanisme tanpa beban 80.076 detik dalam 4 putaran kWh

$\mathrm{P}_{\mathrm{TB}} \quad=4$ putaran/detik

$$
=174 \text { putaran/jam }
$$




\title{
Published Maret 2019 \\ Jurnal Rekayasa Material, Manufaktur dan Energi http://jurnal.umsu.ac.id/index.php/RMME
}

c. Rugi mekanisme dengan beban didapat 76,02 detik dalam 5 putaran pada $\ell(0,70)$

$\mathrm{P}_{\mathrm{TB}} \quad=5$ putaran/detik $=239$ putaran/jam

Berdasarkan percobaan yang dilakukan hasil pengujian daya pada mesin pemecah buah kolang - kaling ini adalah :

\section{Data Kerugian Daya Elektro Motor.}

Kondisi awal : elektro motor tanpa beban

Waktu uji : 112,42 Detik

Kuat Arus : 0,645 Ampere

Tegangan : 220 Volt

Di perolah data $\mathrm{kWh}: 2,13$ putaran

\section{Data kerugian mekanisme dengan motor tanpa beban}

Waktu Uji : 26,25 Detik

Kuat Arus : 0,878 Ampere

Tegangan : 220 Volt

Diperoleh data $\mathrm{kWh}: 2,9$ putaran

\author{
Data kerugaian mekanisme dengan beban \\ pada density $0,70 \mathrm{~kg} / \mathrm{liter}$ \\ Waktu Uji :75,13 Detik \\ Kuat Arus : 1,18 Ampere \\ Tegangan : 220 Volt \\ Diperoleh data $\mathrm{kWh}: 3,9$ putaran
}

Dari data tabel diatas dapat diambil nilai dari rugi-rugi mekanisme, rugi-rugi mekanisme 0,70 $\mathrm{kg} / \mathrm{liter}$ dengan beban sebagai berikut :

- Rugi-rugi mekanisme $=0,77$ putaran

- Rugi-rugi mekanisme dengan beban pada density $0,70=1$ putaran

Pada putaran $48(\mathrm{rpm})$ untuk nilai rugi - rugi mekanisme dan rugi - rugi beban dengan density $0,70 \mathrm{~kg} / \mathrm{literdi}$ peroleh:

a. Rugi - rugi mekanisme $=0,77$ putaran $/$ menit $x \frac{\text { menit }}{\text { jam }}=46,2$ putaran/jam

b. Rugi -rugi mekanisme dengan beban density $0,70 \mathrm{~kg} / \mathrm{liter}$

$$
=1 \text { putaran } / \text { menit } x \frac{\text { menit }}{\text { Jam }}=160 \text { putaran } / \mathrm{jam}
$$

Dari hasil pengujian dengan putaran $60(\mathrm{rpm})$ diperoleh putaran $\mathrm{kWh}$ selama (t) detik adalah $\mathrm{x}$ putaran,dan di analisa diperoleh :

a. Rugi elektro motor 112.42 detik dalam 4 putaran $\mathrm{kWh}$

$\mathrm{P}_{\mathrm{TB}}=4$ putaran/detik

$$
=\frac{60(s)}{112.42(s)} \times 4=2,13 \text { putaran } / \text { menit } \mathrm{x} \frac{\text { menit }}{\text { jam }}=127,8 \text { putaran } / \mathrm{jam}
$$

b. Rugi mekanisme tanpa beban 66.73 detik dalam 4 putaran $\mathrm{kWh}$

$\mathrm{P}_{\mathrm{TB}} \quad=4$ putaran/detik

$$
=\frac{60(s)}{66.73(s)} \times 4 \quad=4,4 \text { putaran } / \text { menit } \mathrm{x} \frac{\text { menit }}{\text { jam }}=264 \text { putaran } / \mathrm{jam}
$$

c. Rugi mekanisme dengan beban didapat 63.279 detik dalam 5 putaran pada $0,70 \mathrm{~kg} / \mathrm{liter}$

$\mathrm{P}_{\mathrm{TB}} \quad=5$ putaran $/$ detik

$$
=\frac{60(s)}{63.729(s)} \times 5 \quad=4,7 \text { putaran } / \text { menit } x \frac{\text { menit }}{\text { jam }}=282 \text { putaran } / \text { jam }
$$




\section{Published Maret 2019 \\ Jurnal Rekayasa Material, Manufaktur dan Energi http://jurnal.umsu.ac.id/index.php/RMME}

Berdasarkan percobaan yang dilakukan hasil pengujian daya pada mesin pemecah buah aren ini adalah :

Data Kerugian Daya Elektro Motor.

Kondisi awal :elektro motor tanpa beban

Waktu uji : 112,42 Detik

Kuat Arus : 0,645 Ampere

Tegangan : 220 Volt

Di perolah data $\mathrm{kWh}: 2,13$ putaran
Data kerugaian mekanisme dengan beban pada density $0,70 \mathrm{~kg} / \mathrm{liter}$

Waktu Uji : 50,53 Detik

Kuat Arus : 1,2 Ampere

Tegangan : 220 Volt

Diperoleh data kWh : 5,9 putaran

\section{Data kerugian mekanisme dengan motor tanpa} beban

Waktu Uji : 53.384 Detik

Kuat Arus : 1,35 Ampere

Tegangan : 220 Volt

Diperoleh data $\mathrm{kWh}: 4,49$ putaran

Dari data tabel diatas dapat diambil nilai dari rugi-rugi mekanisme, rugi-rugi mekanisme 0,70 $\mathrm{kg} /$ literdengan beban sebagai berikut:

- $\quad$ Rugi-rugi mekanisme $=2,36$ putaran

- Rugi-rugi mekanisme dengan beban pada density $0,70=1,41$ putaran

- Pada putaran $72(\mathrm{rpm})$ untuk nilai rugi - rugi mekanisme dan rugi - rugi beban dengan density 0,70 $\mathrm{kg} / \mathrm{literdi}$ peroleh:

- Rugi - rugi mekanisme $=2,36$ putaran $/$ menit $\mathrm{x} \frac{\text { menit }}{\text { jam }}=141,6$ putaran $/ \mathrm{jam}$

- Rugi -rugi mekanisme dengan beban density $0,70 \mathrm{~kg} / \mathrm{liter}=1,41$ putaran $/$ menit $\times \frac{\text { menit }}{\text { Jam }}=$ 84,6 putaran/jam

\section{Pengaruh Kapasitas Terhadap energy}

Dari hasil pengujian pada mesin pemecah buah aren diperoleh hasilnya dan ditabulasi ke dalam tabel di bawah ini dan hasilnya adalah sebagai berikut;

Pada aren dengan putaran $48(\mathbf{r p m})$

$\begin{array}{ll}\text { Kapasitas } & =15,78(\mathrm{Kg} / \mathrm{Jam}) \\ \text { Daya } & =265(\mathrm{Watt})\end{array}$

Putaran $\quad=48(\mathrm{rpm})$
Pada aren dengan putaran $72(\mathbf{r p m})$

Kapasitas $\quad=23,74(\mathrm{Kg} / \mathrm{Jam})$

Daya $\quad=395$ (Watt)

Putaran $\quad=72 \quad(\mathrm{rpm})$

Pada aren dengan putaran $\quad 60(\mathbf{r p m})$

Kapasitas $\quad=19.047(\mathrm{Kg} / \mathrm{Jam})$

Daya $\quad=313$ (Watt)

Putaran $=60(\mathrm{rpm})$

\section{Analisa Grafik}

Tabel 3. Analisa Grafik Antara Putaran Kerja(rpm) Vs Kapasitas(Kg/Jam)

\begin{tabular}{|l|r|r|}
\hline No & $\begin{array}{c}\text { Putaran kerja } \\
(\mathrm{rpm})\end{array}$ & \multicolumn{1}{|c|}{$\begin{array}{c}\text { Kapasitas } \\
(\mathrm{Kg} / \mathrm{Jam})\end{array}$} \\
\hline 1 & 48 & 15,78 \\
\hline 2 & 60 & 19,047 \\
\hline 3 & 72 & 23,74 \\
\hline
\end{tabular}

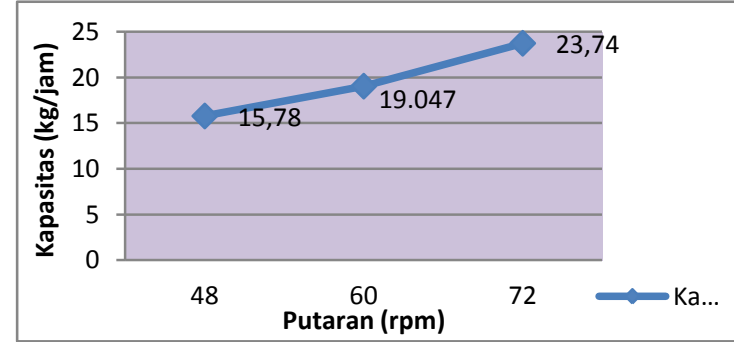

Gambar 3. Grafik kapasitas dan putara

Copyright ${ }^{\odot} 2019$ Jurnal Rekayasa Material, Manufaktur dan Energi. This is an open acces article under the CC-BY-SA lisence (https://creativecommons.org/licenses/by-sa/4.0/). 


\section{Published Maret 2019 \\ Jurnal Rekayasa Material, Manufaktur dan Energi http://jurnal.umsu.ac.id/index.php/RMME}

Tabel 4. Analisa Grafik Antara Kapasitas(rpm) Vs Daya $(\mathrm{Kg} / \mathrm{Jam})$

\begin{tabular}{|l|r|r|}
\hline No & $\begin{array}{c}\text { Kapasitas } \\
(\mathrm{Kg} / \mathrm{Jam})\end{array}$ & \multicolumn{1}{c|}{$\begin{array}{c}\text { Daya } \\
\text { (Watt) }\end{array}$} \\
\hline 1 & 15,78 & 265 \\
\hline 2 & 19,047 & 313 \\
\hline 3 & 23,74 & 395 \\
\hline
\end{tabular}

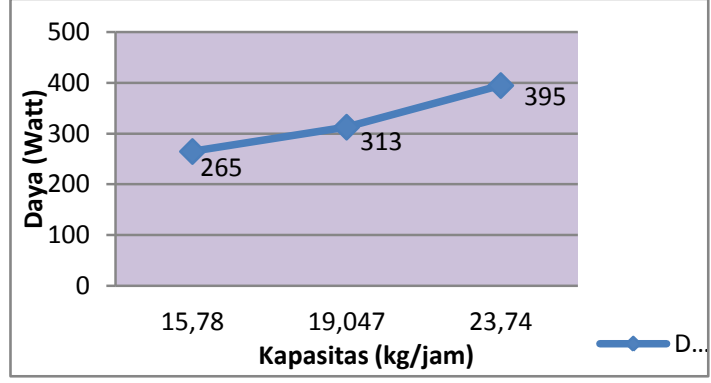

Gambar 4. Grafik kapasitas dan daya

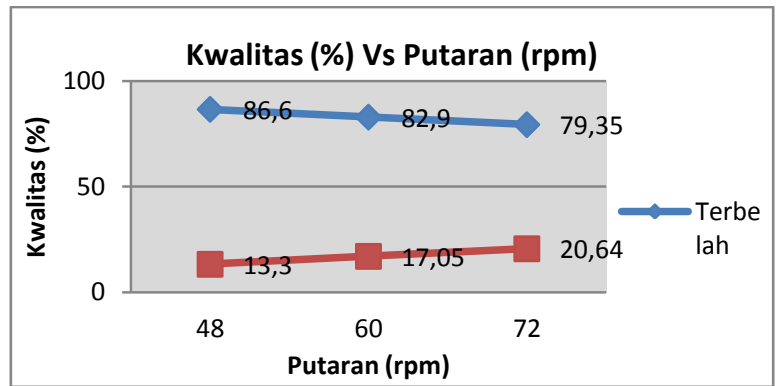

Gambar 5. Grafik putaran dengan kualitas

\section{Interprestasi Hasil}

\section{Data hasil pengujian kapasitas.}

Pada putaran kerja48 rpm diperoleh kapasitas total $15,78 \mathrm{~kg} / \mathrm{jam}$.

Pada putaran kerja60 rpm diperoleh kapasitas total $19,047 \mathrm{~kg} / \mathrm{jam}$.

Pada putaran kerja72 rpm diperoleh kapasitas total $23,74 \mathrm{~kg} / \mathrm{jam}$

Data hasil pengujian kwalitas.

Pada putaran kerja48 rpm,

Buah aren terbelah $=86,6 \%$

Buah aren tidak terbelah $=13,30 \%$

Pada putaran kerja60 rpm,

Buah aren terbelah $=82,9 \%$

Buah aren tidak terbelah $=17,05 \%$

Pada putaran kerja72 rpm,

Buah aren terbelah $=79,35$

Buah aren tidak terbelah $=20,64 \%$

Data hasil pengujian daya produksi.

Pada putaran kerja $48 \mathrm{rpm}$,

Daya produksi $=16,7 \mathrm{Watt} / \mathrm{Kg}$.

Pada putaran kerja $60 \mathrm{rpm}$,

Daya produksi $=16,43 \mathrm{Watt} / \mathrm{Kg}$.

Pada putaran kerja $72 \mathrm{rpm}$,

Daya produksi $=16,63 \mathrm{Watt} / \mathrm{Kg}$.

Data daya yang di hasilkan dengan density 0,70

$\mathrm{kg} / \mathrm{liter}$

Pada putaran kerja $48 \mathrm{rpm}$,

Daya $=265$ Watt

Pada putaran kerja 60 rpm,

Daya $=313$ watt

Pada putaran kerja $72 \mathrm{rpm}$,

Daya $=395$ watt.

\section{KESIMPULAN}

Setelah dilakukan pengujian dengan mesin pemecah buah arendengan hasil yang dapat diterima, dengan yang direncanakan. Sehingga berdasarkan tujuan dari pengujian ini yaitu: untuk mengetahui pengaruh putaran terhadap kapasitas; untuk mengetahui Pengaruh densiti buah aren 


\section{Published Maret 2019 \\ Jurnal Rekayasa Material, Manufaktur dan Energi http://jurnal.umsu.ac.id/index.php/RMME}

terhadap kualitas hasil proses pemecahan buah aren; untuk mengetahui pengaruh kapasitas terhadap energy atau daya mesin yang digunakan ; Hasilnya dapat disimpulkan sebagai berikut:

Hasil Hubungan Antara Variasi Putaran Terhadap Kapasitas Produksi

1. Variasi diameter rodagigi

Variasi diameter rodagigi yang digerakkan :15,8 $(\mathrm{cm}) ; 12,8(\mathrm{~cm})$ dan 10,57 $(\mathrm{cm})$

2.Variasi Putaran pada poros pemutar

Untuk Roda gigi, $d_{1}=10,57(\mathrm{~cm})$ pada poros yang terpasang pada out put reduser dengan putaran 72,5 (rpm).

Untuk roda gigi yang berdiameter $\mathrm{d}_{2}$ :

$\begin{array}{ll}15,8(\mathrm{~cm}) \text { putarannya } & =48(\mathrm{rpm}) ; \\ 12,6(\mathrm{~cm}) \text { putarannya } & =60(\mathrm{rpm}) ; \\ \text { dan } 10,57(\mathrm{~cm}), \text { putarannya } & =72(\mathrm{rpm})\end{array}$

Hasil Pengaruh Antara Density Buaharen Terhadap Kualitas Dan Kapasitas. Semakin besar putaran kerja maka hasil kapasitas pemecahan buah aren akan semakin tinggi kapasitasnya akan tetapi mesin pemecah buaha ren ini tidak mampu menghasilkan pemukulan pada putaran tinggi diakibatkan terjadinya hancurnya buah yang akan di belah pada saat pembelahan

Dengan waktu pemecahan selama 60 detik atau satu menit, pengaruh antara density buah aren terhadap kualitas, tidak terlalu siknifikan perubahan yang terjadi.

Hasil Kapasitas Terhadap Energy Atau Daya Yang Digunakan

Pada putaran 48 daya yang dihasilkan dengan beban dari density $\ell(0,70)$ sebesar 265 (watt), dengan kapasitas yang dihasilkan $15,78 .(\mathrm{kg} / \mathrm{jam})$. Pada putaran $60 \mathrm{rpm}$ daya yang dihasilkan dengan beban dari density $\ell(0,70)$ sebesar 313 (watt), dengan kapasitas yang dihasilkan 19,047 $(\mathrm{kg} / \mathrm{jam})$. Pada putaran 72 daya yang dihasilkan dengan beban dari density $\ell(0,70)$ sebesar 395 (watt), dengan kapasitas yang dihasilkan 23,74(kg/jam). Semakin besar energi/daya maka kapasitas produksi juga semakin besar

\section{DAFTAR PUSTAKA}

[1] Hartanto, Sugiarto, dan Sato Takeshi. 1992. Menggambar Mesin Menurut Standar ISO. Jakarta: PT. PradnyaParamita.

[2] Sularso dan Suga, Kiyokatsu. 2004. DasarPerencanaan dan PemilihanElemenMesin. Jakarta: Pradnya Paramita.

[3] http://sentrablog.blogspot.com/2010/01/manfaat-dan-khasiat-buah-pinang.html

[4] Lias2009,AnalisaUjiKinerjamesinpembelahpinangkapasitas $250 \mathrm{Kg} / \mathrm{Jam}$ InstitutTeknologi Medan (ITM).

[5] Niemann H. Winter “ElemenMesin”edisikedua, PenerbitErlangga 1992, Jakarta. Kanginan,Marthen.2002.FISIKA.Jakarta : Erlangga

[6] http://sentrablog.blogspot.com/2010/01/manfaat-dan-khasiat-buah-pinang.html

[7] http://tanamankampung.blogspot.com/2012/07/pinang.html 